\title{
Egg Development of Paralichthys orbignyanus (Valenciennes, 1839)
}

\author{
Vinicius Ronzani Cerqueira* \\ Laboratório de Piscicultura Marinha; Departamento de Aqüicultura; Centro de Ciências Agrárias; Universidade \\ Federal de Santa Catarina; vrcerqueira@cca.ufsc.br; 88.040-970; Florianópolis -SC-Brazil
}

\begin{abstract}
Eggs of the Southern Brazilian flounder Paralichthys orbignyanus were obtained through spawning induction and reared in laboratory. The eggs released were free-floating or pelagic. Other important characteristics were: spherical shape, smooth chorion, narrow perivitelline space, and a single oil globule. Egg and oil globule diameter were about $0.792 \pm 0.008 \mathrm{~mm}$ and $0.114 \pm 0.003 \mathrm{~mm}$, respectively. The blastodisc was observed approximately $1 \mathrm{~h}$ after fertilization and followed by blastodisc cleavage. Blastula stage started after about $5 \mathrm{~h}$ and gastrula stage after 9 h. Approximately 20 h after fertilization, blastopore closure was observed. Neurula or early embryo occurred after 24 h. Cardiac beats and movements of the free embryonic tail were recorded after $40 \mathrm{~h}$ of incubation. Hatching occurred after an incubation period of 40-50 hat temperatures ranging from 18 to $20^{\circ} \mathrm{C}$. Newly hatched larvae were about 2.04 $\pm 0.024 \mathrm{~mm}$ long and quite undeveloped, with a large yolk sac with a posterior oil globule and sparse pigmentation. These results were greatly similar to those obtained by previous studies regarding congener species. This is one of the first steps towards the artificial propagation of this species under controlled conditions.
\end{abstract}

Key words: Flounder, Paralichthys orbignyanus, egg, embryo, development

\section{INTRODUCTION}

Flounders of the genus Paralichthys, belonging to the order Pleuronectiformes, have both eyes on the left side of the body, which is highly compressed (Ahlstrom et al., 1984). According to Lema et al. (1980), they pertain to the family Bothidae and subfamily Paralichthinae. However, Ahlstrom et al. (1984) and Figueiredo and Menezes (2000) placed this genus in the family Paralichthyidae. Several species of this order are of great commercial importance for aquaculture and are being reared worldwide (Ikenoue and Kafuku, 1992; Lavens and Remmerswaal, 1994; Alvial and Manríquez, 1999; Bengtson, 1999; Olsen et al., 1999).
There are many flatfish species commercially exploited by fisheries along the southern Atlantic coast of America (Brazil, Uruguay and Argentina), due to their high quality food value, but they are not produced through aquaculture yet. Lema et al. (1980) provided a list of pleuronectiforms inhabiting areas from Santa Catarina state (Brazil) to Rio de La Plata (Argentina), emphasizing the occurrence of the flounder Paralichthys orbignyanus (Valenciennes, 1839). In Rio Grande do Sul state (Brazil, lat. $29^{\circ} \mathrm{S}-34^{\circ} 40^{\prime} \mathrm{S}$ ), $P$. orbignyanus and Patagonian Flounder $P$. patagonicus Jordan, 1889 are very important (Haimovici et al., 1996) for artisanal and industrial fisheries, respectively.

\footnotetext{
*Author for correspondence
} 
There is scant information on the reproductive biology of south Atlantic flatfish species. Silveira et al. (1995) studied some aspects of P. orbignyanus reproduction in the estuary of Patos Lagoon and nearby coastal waters (lat. $32^{\circ} \mathrm{S}$ ). Cerqueira et al. (1997) obtained artificial spawning of wild $P$. orbignyanus specimens, through hormonal induction. On the other hand, the rearing of juveniles of this species has succeeded experimentally (Sampaio et al., 2001).

The egg and larval development of two congener species inhabiting the Pacific coast of South America, Paralichthys adspersus (Steindachner, 1887) and P. microps (Gunther, 1881), has already been described (Silva, 1988; Silva and Flores, 1989; Zuñiga and Acuña, 1992). The early life history stages of some flounder species from the northern hemisphere, namely the bastard halibut $P$. olivaceus (Temminck and Schlegel, 1846), summer flounder $P$. dentatus (Linnaeus, 1766), the California flounder P. californicus (Ayres, 1859) (Ahlstrom et al., 1984), gulf flounder $P$. albigutta Jordan and Gilbert, 1882 and southern flounder $P$. lethostigma Jordan and Gilbert, 1884 (Powell and Henley, 1995), are well known.

Knowledge of early life history stages of fish is essential for rearing studies, but also for those regarding exploitation of wild stocks. Artificial propagation is an excellent tool for this purpose. The objective of this work was to study the main morphological characteristics of the egg development stages of the flounder $P$. orbignyanus under experimental conditions.

\section{MATERIALS AND METHODS}

The methodology employed in the artificial propagation was developed at the Marine Fish Culture Laboratory (Universidade Federal de Santa Catarina). Experiments were carried out during winter months (July to September) in 1995 and 1996, during natural spawning season. In this study, data obtained in some trials are summarized. The technique adopted in the artificial reproduction was the same described by Cerqueira et al. (1997), with slight adaptations.

\section{Brood Stock and Spawning Induction}

Adult flounders in advanced sexual maturity stage were caught by artisanal fishermen in Conceição Lagoon and Barra da Lagoa Beach (Florianópolis Santa Catarina), using fishing nets. Sometimes, caught females were in process of ovulation and hormonal induction was unnecessary. Otherwise, the hormone human Chorionic Gonadotropin (hCG commercial grade) was injected intramuscularly at $250-500 \mathrm{IU} / \mathrm{kg}$ in males, and at 500-1,000 IU/kg in females, depending on sex maturity. Gametes were obtained through strip spawning. Artificial fertilization was performed by the dry method, spreading milt over the eggs, adding a small volume (10-20 mL) of saltwater (35 g/L) and mixing altogether. Some minutes later, the eggs were washed in a current of new water to eliminate debris, and finally placed into incubators.

\section{Eggs Incubation}

For the incubation, 35-L cylinder-conical tanks were placed inside a rectangular 1,000-L tank, with water exchange at $10-20 \% / \mathrm{h}$ and continuous aeration provided by air stones. Stocking density varied from 1,000 to 3,000 eggs/L. Salinity was around $35 \mathrm{~g} / \mathrm{L}$ and water temperature was $18-20{ }^{\circ} \mathrm{C}$.

\section{Sampling and Description of Eggs and Larvae}

In order to describe morphology and measure eggs and newly hatched larvae in vivo, periodic samples $(n \geq 30)$ were taken directly from the incubators, by using a beaker. Observation intervals were at least $30 \mathrm{~min}$ apart, depending on the occurrence of main events. Observations were made under a light microscope with a 10x eyepiece and a 10x objective, coupled to a video camera and a color monitor. The most representative images were printed. Determination of developmental stages was based on description, and terminology proposed by Lagler et al. (1977) and Balinsky (1981). Morphometric data were collected, to the nearest $0.01 \mathrm{~mm}$ using an ocular micrometer, from eggs (total diameter and oil globule diameter) and from yolk-sac larvae (total length, yolk-sac length, and oil globule diameter). For each variable, the average, standard deviation, and confidence interval (significance level of 5\%) were calculated.

\section{RESULTS}

\section{Morphological Aspects and Size of Eggs and Larvae}

Right after fertilization and placement into the incubators, eggs were pelagic, free, round and transparent. They had a single and small oil globule. Appearance of the yolk was homogeneous. The chorion was smooth and thin, whereas the 
perivitelline space was narrow. Eggs had a mean diameter of $0.792 \pm 0.008 \mathrm{~mm}$, and mean oil globules diameter was $0.114 \pm 0.003 \mathrm{~mm}$ (Table 1). Just after hatching, the yolk sac with its oil globule represented the largest volume of the larvae. Length of the yolk sac $(0.972 \pm 0.015 \mathrm{~mm})$ was equivalent to approximately $50 \%$ of total length $(2.04 \pm 0.024$ $\mathrm{mm})$. The single oil globule had a mean diameter of $0.098 \pm 0.006 \mathrm{~mm}$ (Table 1).

\section{Egg Development Stages}

Egg development was divided into eight stages, from fertilization to hatching, corresponding to the main events. Only the most important morphological characteristics of each stage were registered.

Table 1 - Measurements of eggs and yolk-sac larvae of southern Brazilian flounder, Paralichthys orbignyanus.

\begin{tabular}{lccccc}
\hline Measure & Mean $(\mathbf{m m})$ & $\begin{array}{c}\text { Standard } \\
\text { deviation }\end{array}$ & $\begin{array}{c}\text { Confidence } \\
\text { interval }( \pm)\end{array}$ & $\begin{array}{c}\text { Range } \\
(\mathbf{m m})\end{array}$ & $\mathbf{n}$ \\
\hline Eggs & & & & & \\
Diameter & 0.792 & 0.025 & 0.008 & $0.744-0.860$ & 40 \\
Oil globule diameter & 0.114 & 0.005 & 0.003 & $0.105-0.116$ & 30 \\
Larvae & & & & & \\
Total length & 2.040 & 0.038 & 0.024 & $1.980-2.090$ & 30 \\
Yolk-sac length & 0.972 & 0.024 & 0.015 & $0.930-1.000$ & 30 \\
Oil globule diameter & 0.098 & 0.010 & 0.006 & $0.081-0.116$ & 30 \\
\hline
\end{tabular}

Fertilization: Approximately $60 \mathrm{~min}$ after fertilization, the cytoplasmic cap on the animal pole was formed that contained the nucleus, in opposition to the vegetal pole with the yolk and a thin layer of cytoplasm surrounding the yolk.

Cleavage: After successive divisions in the animal pole the blastoderm formed, following the typical pattern of telolecithal eggs. First division occurred $1 \mathrm{~h} 30 \mathrm{~min}$ after fertilization, and resulted in the formation of two cells or blastomeres (Fig. 1a). Following that, at $1 \mathrm{~h} 50 \mathrm{~min}$ after fertilization, were four cells (Fig. 1a), then eight cells ( 2 h 20 min), 16 cells ( 3 h 00 min) (Fig. 1b), 32 cells ( $3 \mathrm{~h}$ $30 \mathrm{~min}$ ), and 64 cells (4 h $20 \mathrm{~min}$ ). More than 64 small blastomeres were impossible to enumerate in vivo.

Blastula: In the beginning, between $5 \mathrm{~h} 10 \mathrm{~min}$ and $6 \mathrm{~h} 00 \mathrm{~min}$ after fertilization, the blastoderm had the shape of a convex disc on the animal pole (blastodisc). At the end, between $6 \mathrm{~h} 00 \mathrm{~min}$ and $7 \mathrm{~h}$ $00 \mathrm{~min}$ after fertilization, there was a flattening of the blastoderm and formation of a syncytial layer (periblast) at the interface of the animal and vegetal poles (Fig. 1c).

Gastrula: In the initial stage, 9 h 00 min after fertilization, there was a thickening of the marginal ridge of the blastodisc, forming an inner layer called the germ ring. A cellular growth occurred to cover the yolk mass, a movement of the blastodisc termed epiboly (Fig. 1d). In the advanced stage, between $15 \mathrm{~h} 00 \mathrm{~min}$ and $15 \mathrm{~h} 30 \mathrm{~min}$ after fertilization, the process of epiboly resulted in covering practically $2 / 3$ of the yolk mass by mesodermic and ectodermic tissue. In the dorsal region the embryonic shield, forming since the initial gastrula, could be observed. At the end, $16 \mathrm{~h} 00 \mathrm{~min}$ after fertilization, the neural keel became more clearly visible in the midline of the embryonic shield. The yolk plug, a very restricted region of the yolk, was not covered by the blastoderm (Fig. 1e).

Blastopore Closure: The edges of the blastodisc surrounded the entire yolk, converged and closed at the posterior end of the embryo, approximately $20 \mathrm{~h}$ after fertilization. The cephalic region, with rudiments of the central nervous system, the first somites, and the caudal region became visible. An enlargement of the perivitelline space was obvious.

Embryo: In the initial stage, $24 \mathrm{~h}$ after fertilization, the process of neurulation was taking place. The cephalic and caudal edges of the embryo were well differentiated. There was an expansion of the forebrain. The neural plate was quite distinct (Fig. 1f). Following that, there was formation of the optic vesicles, brain and Kupffer's vesicles, and olfactory pits. 

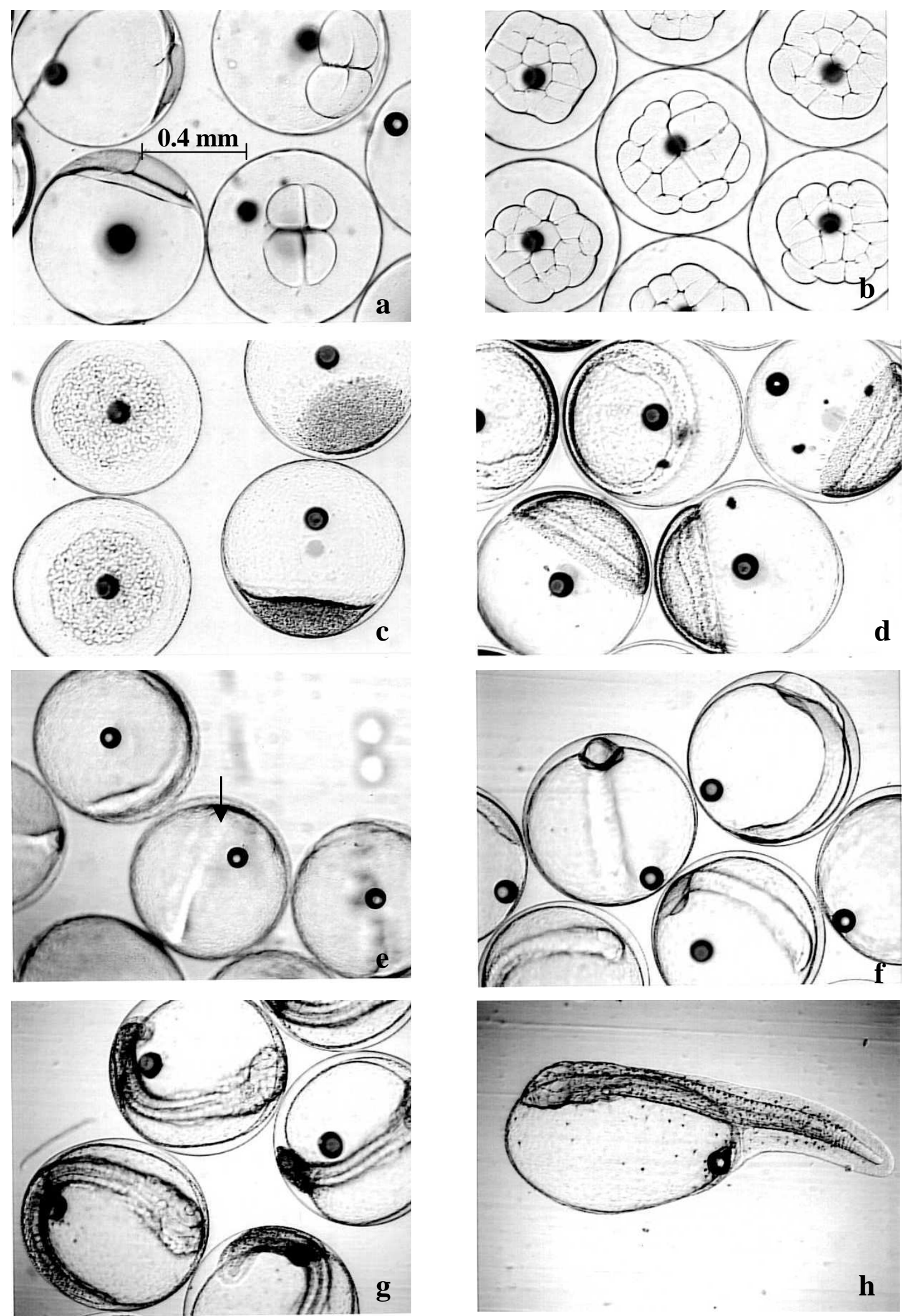

Figure 1 - Development of laboratory-reared eggs and newly hatched larvae of southern Brazilian flounder, Paralichthys orbignyanus. Developmental stages: a- Cleavage, 2 and 4 blastomeres; b- Cleavage, 16 blastomeres; c- Blastula (early stage); d- Gastrula (early stage); e- Gastrula (late stage) and blastopore closure (arrow); f- Embryo (early stage); g- Embryo (late stage); h- Newly hatched larva. 
In the advanced embryo, $40 \mathrm{~h}$ after fertilization, melanophores were more evident over the body and yolk sac.

The number of somites was increasing, auditory placodes were visible, and lens of eyes were forming in the optic vesicles. There were cardiac beats, an increase in perivitellline space, and tail liberation inside the chorion, where it was free of movement (Fig. 1g).

From a ventral view of the head and trunk of the embryo, the neural tube and notochord, somites, eye lenses, olfactory placodes, cardiac region, and yolk sac pigmentation were clearly visible.

Hatching: Approximately $41 \mathrm{~h}$ after fertilization, there was vigorous activity of the embryo in some eggs, rupture of the chorion and liberation of the embryo. The hatching interval for larvae from a single batch could take a few hours. At water temperatures near $20^{\circ} \mathrm{C}$, time to hatching was about $41 \mathrm{~h}$, but at $18{ }^{\circ} \mathrm{C}$ or lower it could be prolonged to about $50 \mathrm{~h}$.

Yolk-sac larva: Newly hatched larva, or freeembryo according to Balon (1975), had a large elliptical yolk sac, with a single posterior oil globule. A continuous median finfold (dorsal, anal, and caudal) surrounded the trunk and the tail. Larvae lacked a functional mouth and digestive tract, which presented only rudiments. Iris of the eyes had no pigments. Otoliths, heart, and brain were clearly visible. Body pigmentation was still sparse, with few melanophores on the dorsal and anal finfolds. Pigment was more developed in the ventral and dorsal midlines and on the lateral surface, except at the tail end. Pigment was rare but present on the yolk sac, primarily on the dorsal portion and around the oil globule (Fig. 1h).

\section{DISCUSSION}

\section{Eggs}

Paralichthys orbignyanus eggs present the basic patterns of most marine fishes: they are pelagic and float individually near the surface, are spherical with a diameter around $1 \mathrm{~mm}$, and hatch into undeveloped yolk-sac larvae (Kendall et al., 1984). $P$. orbignyanus eggs are quite similar to other congener flounder eggs. Ahlstrom et al. (1984) summarized data from different studies, including seven species of the family Paralichthydae among those pleuronectiforms having pelagic eggs with a single oil globule. Egg diameter in these species varied from 0.7 to $1.38 \mathrm{~mm}$, and the oil globule between 0.10 and $0.31 \mathrm{~mm}$. They were round, had a narrow to moderate perivitelline space, homogeneous yolk and smooth chorion. Among the congeners mentioned by Ahlstrom et al. (1984), $P$. californicus $(0.74-0.82 \mathrm{~mm}), P$. dentatus $(0.90-1.10$ $\mathrm{mm})$, and $P$. olivaceus $(0.83-1.03 \mathrm{~mm})$ had egg diameters very close to $P$. orbignyanus $(0.74-0.86$ $\mathrm{mm})$. On the same note, the egg and oil globule diameters of $P$. albigutta $(0.84-0.90 \mathrm{~mm}$ and 0.17 $0.19 \mathrm{~mm})$ and P. lethostigma $(0.84-0.96 \mathrm{~mm}$ and 0.16-0.20 mm) were comparable to $P$. orbignyanus (Powell and Henley, 1995).

In a laboratory study, Silva (1988) described a very similar pattern of egg development for P. microps (egg diameter $0.8 \mathrm{~mm}$ ), compared to $P$. orbignyanus in the present study. First segmentation occurred in almost the same time interval after fertilization, despite a low temperature range $\left(13-17^{\circ} \mathrm{C}\right)$. From gastrula stage $(12 \mathrm{~h} 30 \mathrm{~min})$ onwards, differences became more evident between the two species, likely due to temperature. Blastopore closure (24 h $30 \mathrm{~min}$ ), appearance of optic vesicles ( $46 \mathrm{~h}$ ), and the embryo with cardiac beats and tail movements $(52 \mathrm{~h})$ were also noted later than in P. orbignyanus $(20 \mathrm{~h}, 25 \mathrm{~h}$, and $40 \mathrm{~h}$, respectively). Also, the time to hatching, occurred 57-68 h after fertilization for P. microps, quite longer than the time observed for $P$. orbignyanus (40-50 h). Silva and Flores (1989) reported an incubation time of 54-62 h for P. adspersus at 16$18^{\circ} \mathrm{C}$. Gadomski and Caddell (1996) observed that temperature $\left(12-20{ }^{\circ} \mathrm{C}\right)$ strongly affected rate of development in $P$. californicus eggs and was inversely related to time to hatching. Time intervals to blastopore closure were 34,24 and $17 \mathrm{~h}$, and hatching time intervals were 74,50 and $34 \mathrm{~h}$, respectively, for 12,16 and $20{ }^{\circ} \mathrm{C}$. If we consider only the 16 and $20^{\circ} \mathrm{C}$ interval values, they are quite close to the values observed in the present study. However, species-specific differences in egg-stage sequence, mainly of organogenesis in relation to germ ring migration and blastopore closure, were also found. The sequence of main events described for $P$. californicus and for the other congeners was basically the same observed for P. orbignyanus.

\section{Yolk-Sac Larvae}

Some morphological aspects of the newly hatched larva could be important in terms of systematics. For example, in the family Paralichthyidae, the single oil globule is usually in the rear of the yolk 
mass (Ahlstrom et al., 1984). Moreover, other aspects of the $P$. orbignyanus larva, as the elliptical yolk sac, corresponding to approximately half of the larval length, single median finfold, undifferentiated mouth, rudimentary digestive tract, and unpigmented eyes are common to $P$. microps, $P$. adspersus, $P$. albigutta e $P$. lethostigma (Silva, 1988; Silva and Flores, 1989; Powell and Henley, 1995). Concerning pigmentation, there may be differences that are helpful in some cases in the identification of distinct species. Powell and Henley (1995) observed that P. lethostigma had pigment more concentrated in the middle of the body (dorsal and anal finfolds, and dorsal midline), and was less pigmented than $P$. albigutta. Zuñiga and Acuña (1992) verified that $P$. adspersus had melanophores in only some areas of the head, trunk and dorsal region of the yolk sac, whereas $P$. microps had melanophores also in the median finfold. Paralichthys orbignyanus larva had melanophores in almost all parts of the body as well.

Total length at hatching of $P$. orbignyanus larva was $2.04 \mathrm{~mm}$. Ahlstrom et al. (1984) reported a total length of $2.0 \mathrm{~mm}$ for $P$. californicus, 2.4-2.8 $\mathrm{mm}$ for $P$. dentatus, and $2.6-2.8 \mathrm{~mm}$ for $P$. olivaceus. Silva (1988) observed a total length of $2.7 \mathrm{~mm}$ for P. microps larva, while Silva and Flores (1989) reported that $P$. adspersus larva was $1.9 \mathrm{~mm}$ in length. Powell and Henley (1995) described notochord length of $P$. albigutta $(1.8-2.0 \mathrm{~mm})$ and of $P$. lethostigma (2.0-2.2 mm). Among 26 species of the family Paralichthydae listed by Ahlstrom et al. (1984), only four had body lengths higher than $2.3 \mathrm{~mm}$. Therefore, $P$. orbignyanus seemed to correspond to the body length pattern observed for this family, and could be considered a species with small larvae. This characteristic is important because the larval size define the kind of live prey that the larva will be fed when reared in laboratory (Hunter, 1984).

\section{CONCLUSION}

P. orbignyanus egg development was greatly similar, chronologically and morphologically, to other congeners. Results obtained in the present study demonstrated the feasibility of egg incubation and normal development in laboratory conditions, representing a very important step towards the evaluation of the species potential to be commercially reared in the future.

\section{ACKNOWLEDGEMENTS}

This research was funded by the Conselho Nacional de Desenvolvimento Científico e Tecnológico $(\mathrm{CNPq})$ and Fundação Banco do Brasil. We thank to J. Macchiavello and J. de Araújo for assistance in the laboratory work; P. Dias gave valuable contribution about many aspects of Embryology; E. Zaniboni Filho reviewed the manuscript improving aquaculture aspects; C. Poli, G. Phonlor and N. Castagnolli, provided comments on an earlier version of the manuscript.

\section{RESUMO}

Através do cultivo de ovos do linguado Paralichthys orbignyanus, obtidos de reprodução induzida em laboratório, foram descritos pela primeira vez seus estádios de desenvolvimento. $\mathrm{O}$ ovo era livre e flutuante, caracteristicamente pelágico. Além disso, tinha formato esférico, córion liso, espaço perivitelino estreito, vitelo homogêneo, e uma única gota de óleo. Seu diâmetro médio era de $0,792 \pm 0,008 \mathrm{~mm}$ e o da gota de óleo de $0,114 \pm$ $0,003 \mathrm{~mm}$. Cerca de $1 \mathrm{~h}$ após a fecundação observou-se o blastodisco e em seguida a segmentação celular. A blástula iniciou após cerca de 5 h e a gástrula após $9 \mathrm{~h}$. Com aproximadamente $20 \mathrm{~h}$ observou-se o fechamento do blastóporo. A nêurula ou embrião na fase inicial ocorreu após 24 h. Com cerca de 40 h havia batimentos cardíacos e movimentação da cauda do embrião. A eclosão ocorreu num período de 40 a $50 \mathrm{~h}$ após a fecundação, em temperaturas de 18 a $20^{\circ} \mathrm{C}$. A larva tinha um comprimento total médio de 2,04 $\pm 0,024$ $\mathrm{mm}$, o saco vitelino bastante volumoso, a gota de óleo em sua porção posterior e pigmentação reduzida e esparsa. Estes resultados foram muito similares aos observados anteriormente em outras espécies congêneres.

\section{REFERENCES}

Ahlstrom, E. H.; Amaoka, K.; Hensley, D. A.; Moser, H. G. and Sumida, B. Y. (1984), Pleuronectiformes: development. In: Moser, H. G.; Richards, W. J.; Cohen, D. M.; Fahay, M. P.; Kendall, A. W. and Richardson, S. L. (Eds.). Ontogeny and Systematics of Fish. American Society of Ichthyologists and Herpetolologists, La Jolla (Ca). pp. 640-670. 
Alvial, A.; Manríquez, J. (1999), Diversification of flatfish culture in Chile. Aquaculture, 176, 65-73.

Balinsky, B. I. (1981), Introduction to Embryology. Saunders College Publishing, Philadelphia (Pa), 688 p.

Balon, E. K. (1975), Terminology of intervals in fish development. Journal of the Fisheries Research Board of Canada, 32, 1663-1670.

Bengtson, D. A. (1999), Aquaculture of summer flounder (Paralichthys dentatus): status of knowledge, current research and future research priorities. Aquaculture, 176, 39-49.

Cerqueira, V. R.; Mioso, R.; Macchiavello, J. A. G. and Brügger, A. M. (1997), Ensaios de indução de desova do linguado (Paralichthys orbignyanus Valenciennes, 1839). Boletim do Instituto de Pesca, 24, 247-254.

Figueiredo, J. L. and Menezes, N. A. (2000), Manual de peixes marinhos do sudeste do Brasil. VI. Teleostei (5). Museu de Zoologia, Universidade de São Paulo, São Paulo. 116 pp.

Gadomski, D. M. and Caddell, S. M. (1996), Effects of temperature on the development and survival of eggs of four coastal California fishes. Fishery Bulletin, 94, 41-48.

Haimovici, M.; Martins, A. S. and Vieira, P. C. (1996), Distribuição e abundância de teleósteos marinhos demersais sobre a plataforma continental do sul do Brasil. Revista Brasileira de Biologia, 56, 27-50.

Hunter, J. R. (1984), Synopsis of culture methods for marine fish larvae. In: Moser, H. G.; Richards, W. J.; Cohen, D. M.; Fahay, M. P.; Kendall, A. W. and Richardson, S. L. (Eds.). Ontogeny and Systematics of Fish. American Society of Ichthyologists and Herpetolologists, La Jolla (Ca). pp. 24-27.

Ikenoue, H.and Kafuku, T. (1992), Flatfish (Paralichthys olivaceus). In: Modern Methods of Aquaculture in Japan, Chap. 16, $2^{\text {nd }}$ ed. Kodanska, Tokyo, Elsevier, Amsterdam. pp. 144-149.

Kendall Jr., A. W.; Ahltrom, E. H.and Moser, H. G. (1984), Early life history stages of fishes and their characters. In: Ontogeny and Systematics of Fish, eds. H. G. Moser, W. J. Richards, D. M. Cohen, M.P. Fahay, A.W. Kendall and S.L. Richardson. American Society of Ichthyologists and Herpetolologists, La Jolla (Ca). pp. 11-22.

Lagler, K. F.; Bardach, J. E.; Miller, R. R.and Passino, D. R. M. (1977), Reproduction. In: Ichthyology, Chap. 10. New York : John Wiley and Sons. pp. 268-310.

Lavens, P. and Remmerswaal, R. (Eds.) (1994), Turbot culture: problems and prospects. European Aquaculture Society, Gent, Special Publication, 22, $360 \mathrm{pp}$.

Lema, T.; Oliveira, M. F. T. and Lucena, C. A. S. (1980), Levantamento preliminar dos Pleuronectiformes do extremo sul do Brasil ao Rio de la Plata. Iheringia, 56, 25-52.
Olsen, Y.; Evjemo, J. O. and Olsen, A. (1999), Status of the cultivation technology fro production of Atlantic halibut (Hippoglossus hippoglossus) juveniles in Norway/Europe. Aquaculture, 176, 3-13.

Powell, A. B. and Henley, T. (1995), Egg and larval development of laboratory-reared gulf flounder, Paralichthys albigutta, and southern flounder, $P$. lethostigma (Pisces, Paralichthyidae). Fishery Bulletin, 93, 504-515.

Sampaio, L. A.; Bianchini, A. and Cerqueira, V. R. (2001), Growth of juvenile Brazilian flounder Paralichthys orbignyanus reared in different salinities. Journal of Applied Aquaculture, 11, 67-75.

Silva, A. (1988), Observaciones sobre el desarrollo del huevo y estadios larvarios de lenguado Paralichthys microps (Gunther, 1881). Revista Latinoamericana de Acuicultura, 35, 18-25.

Silva, A.; Flores, H. (1989), Consideraciones sobre el desarrollo y crecimiento larval del lenguado (Paralichthys adspersus Steindachner, 1867) cultivado en laboratorio. Revista del Pacífico Sur (número especial), 629-634.

Silveira, M. P. M.; Cousin, J. C. B. and Haimovici, M. (1995), Estrutura ovárica e testicular do linguado Paralichthys orbignyanus (Valenciennes, 1839). Revista Atlântica, 17, 135-152.

Zuñiga, H. N. And Acuña, E. S. (1992), Larval development of two sympatric flounders, Paralichthys adspersus (Steindachner, 1867) and Paralichthys microps (Gunther, 1881) from the Bay of Coquimbo, Chile. Fishery Bulletin, 90, 607-620.

Received: March 25, 2003; Revised: December 11, 2003; Accepted: September 14, 2004. 